\title{
PENGARUH DEBT FINANCING DAN EQUITY FINANCING TERHADAP PROFIT EXPENSE RATIO PERBANKAN UMUM SYARIAH PERIODE 2011-2015[1]
}

\author{
Amanda Maulidiyah Firdaus \\ Mahasiswa Program Studi S1 Ekonomi Islam-Fakultas Ekonomi dan Bisnis-Universitas Airlangga \\ Email : amanda.maulidiyah-12@feb.unair.ac.id \\ Ari Prasetyo \\ Departemen Ekonomi Syariah-Fakultas Ekonomi dan Bisnis-Universitas Airlangga \\ Email : ari_p@feb.unair.ac.id
}

\begin{abstract}
:
The purpose of this research is to find out the influence of debt financing and equity financing to profit expense ratio. This research is to describe the efficiency of financing in Islamic bank. The research method of this research is the quantitative approach. Character sample used is a quarterly report on three Islamic banks, Bank Muamalat Indonesia, Bank Syariah Mandiri, and BRI Syariah, period of January 2011-December 2015, so the totaling 60 samples. Sampling using purposive sampling. The analysis used the Panel regression analysis. The results showed that the partial debt financing significantly influence the profit expense ratio, and equity financing is also significantly influence the profit expense ratio. Simultaneously, debt financing and equity financing significantly influence of Islamic banking profit expense ratio.
\end{abstract}

\section{Keywords : Debt Financing, Equity Financing, Profit Expense Ratio, Efficiency.}

\section{PENDAHULUAN}

\section{Latar Belakang}

Perbankan berperan sangat penting terhadap pergerakan perekonomian Indonesia. Eksistensi lembaga keuangan khususnya sektor perbankan menempati posisi sangat strategis dalam menjembatani kebutuhan modal kerja dan investasi di sektor riil dengan pemilik dana (agent of economic development ). Fungsi utama sektor perbankan dalam infrastruktur kebijakan makro ekonomi memang diarahkan dalam konteks how to make money effective and efficient to increase economic value (Antonio dkk, 2006:65)

Semakin besarnya penyaluran dana dalam bentuk kredit dibandingkan dengan deposit atau simpanan [1] jurnal ini merupakan bagian dari skripsi yang ditulis oleh Amanda Maulidiyah f; 041211433039 yang diuji pada tanggal 14 Oktober 2016 masyarakat pada suatu bank membawa konsekuensi semakin besarnya risiko yang harus ditanggung oleh bank yang bersangkutan. (Mulyono, 1995:101).

Dalam sistem perbankan konvensional, bank selain berperan sebagai jembatan antara pemilik dana dan dunia usaha, juga masih menjadi penyekat antara keduanya karena tidak adanya transferability risk dan return. (Machmud,2010:7). Berbeda dengan sistem konvensional, pada perbankan syariah, bank menjadi manajer investasi, wakil, atau pemegang amanat (kustodian) dari pemilik dana atas investasi di sektor riil. Seluruh keberhasilan dan risiko dunia usaha atau pertumbuhan ekonomi secara langsung didistribusikan 
Firdaus, et al/Jurnal Ekonomi Syariah Teori dan Terapan Vol. 4 No. 6 Juni 2017: 505-514; PENGARUH DEBT FINANCING DAN EQUITY FINANCING TERHADAP PROFIT EXPENSE RATIO PERBANKAN UMUM SYARIAH PERIODE 2011-2015

kepada pemilik dana sehingga menciptakan suasana harmoni. (Machmud, 2010:7).

Penyaluran dana dilakukan oleh bank syariah melalui pembiayaan dengan empat pola penyaluran yaitu prinsip jual beli, prinsip bagi hasil, prinsip sewa menyewa dan akad pelengkap. Menurut Wirdyaningsih ( 2005:126) Akad yang banyak digunakan dalam pembiayaan pada prinsip jual beli adalah Murabahah, Istishna dan Salam. Pada prinsip bagi hasil terdapat dua akad yakni Mudharabah dan Musyarakah. Sewa menyewa memiliki dua akad yakni ljarah dan ljarah muntahiya bittamlik.

Dana untuk melakukan pembiayaan dalam bank syariah, sebagian besar berasal dari dana pihak ketiga (DPK) yang berasal dari masyarakat yang menjadi nasabah bank tersebut. Porsi pembiayaan pada bank syariah, pada umumnya mencapai $60 \%$ dari total aktiva (Muhammad,2002: 238).

Oleh karena itu, bank syariah harus benar-benar mempersiapkan strategi penggunaan dana-dananya agar tingkat penghasilan dari pembiayaan merupakan tingkat penghasilan yang menempati porsi terbesar. Namun ada masalah seiring dengan pesatnya perkembangan jumlah bank syariah dan jumlah asset dari bank syariah tersebut. Yaitu Pembiayaan mayoritas disalurkan pada debt financing yaitu sebesar $70 \%$ dengan komposisi Murabahah 84\%; lainnya $16 \%$ dari komposisi debt financing, sedangkan pembiayaan bagi hasil (equity financing) hanya sebesar $30 \%$ dengan komposisi Mudharabah 25,5\%; musyarakah $74,5 \%$. Pembiayaan dengan sistem debt financing memang diperbolehkan dalam islam, namun alangkah baik jika dalam praktiknya, pembiayaan dengan sistem equity financing mendapatkan porsi yang lebih besar dibandingkan pembiayaan dengan sistem debt financing mengingat tujuan bank syariah tidak hanya untuk mencari keuntungan. (Sadique, 2010:150).

Berdasarkan uraian di atas, maka masalah - masalah yang diteliti pada penelitian ini adalah :

1. Apakah debt financing dan equity financing berpengaruh secara bersama sama (simultan) terhadap profit expense ratio Perbankan Umum Syariah ?

2. Apakah debt financing berpengaruh secara parsial terhadap profit expense ratio Perbankan Umum Syariah ?

3. Apakah equity financing berpengaruh secara parsial terhadap profit expense ratio Perbankan Umum Syariah?

Adapun tujuan dari penelitian ini adalah Untuk mengetahui pengaruh tingkat Debt Financing dan Equity Financing baik secara simultan maupun parsial terhadap Profit Expense Ratio Perbankan Umum Syariah.

\section{LANDASAN TEORI DAN PENGEMBANGAN HIPOTESIS}

Salah satu pembiayaan yang dikenal di bank syariah adalah 
pembiayaan yang menggunakan Debt Financing atau akad jual beli. Akad pembiayaan jual beli yang dikembangkan oleh bank syariah adalah tiga akad yaitu al-Murabahah,alIstishna, dan as-Salam. Masing-masing jenis akad pembiayaan jual beli ini memiliki ciri khas yang berbeda-beda. Return atas pembiayaan jual beli berasal dari selisih antara harga jual dan harga beli yang disebut dengan margin keuntungan. (Ismail, 201 1:135)

Landasan syariah mengenai jual beli tercantum dalam Al-Qur'an

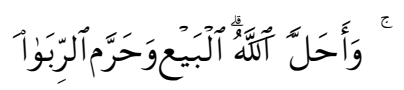

Wa ahalla allahul bay-a wa harram alrribā' "...dan Allah telah menghalalkan jual beli dan mengharamkan ribā" (Departemen Agama Rl, 2013 :47)

Salah satu produk bank syariah yang sangat membedakan dengan bank konvensional adalah pembiayaan kerja sama usaha. Dalam pembiayaan kerja sama usaha, bank tidak membebani bunga kepada nasabah, akan tetapi ikut serta dalam investasi. Hasil investasi akan diterima dalam bentuk bagi hasil atas usaha yang dijalankan oleh nasabah.

Bagi hasil merupakan imbalan yang akan diterima oleh bank syariah atas pembiayaan kepada nasabah. Pembiayaan yang menggunakan konsep kerja sama usaha dibedakan menjadi pembiayaan mudharabah dan musyarakah. Pembiayaan mudharabah merupakan pembiayaan $100 \%$ yang diberikan oleh bank syariah kepada nasabah. Pembiayaan musyarakah merupakan kerja sama usaha, yang masing-masing pihak baik bank syariah maupun nasabah ikut menyertakan modalnya dalam menjalankan usahanya.

Profit Expense Ratio (PER) adalah rasio yang digunakan DR.Abdus Samad dan DR. M.Khabir Hassan dalam menilai kinerja Bank Islam Malaysia periode 19841997 dalam hal profitabilitas. Dimana bila rasio ini menunjukkan profit yang tinggi dengan beban-beban yang harus ditanggungnya. Efisiensi merupakan salah satu parameter kinerja yang secara teoritis merupakan salah satu kinerja yang mendasari seluruh kinerja sebuah organisasi. Manajemen di dalam suatu badan usaha, baik industry, niaga dan jasa, tidak terkecuali jasa perbankan, didorong oleh motif mendapatkan keuntungan (profit). Untuk mendapatkan keuntungan yang besar, manajemen haruslah diselenggarakan dengan efisien. Sikap ini harus dimiliki oleh setiap pengusaha dan manajer di mana pun mereka berada, baik dalam organisasi bisnis, pelayanan public, maupun organisasi social kemasyarakan.

Konsep efisiensi juga menjadi bahasan yang penting pada perbankan Syariah. Dari sudut pandang ekonomi Islam, konsep efisiensi sejalan dengan prinsip syariah yang bertujuan untuk mencapai dan menjaga maqashid syariah yaitu terpeliharanya al-maal (Kamaruddin,et.ali, 2008:33). 
konsep efisiensi pada dasarnya adalah menghindari segala bentuk pemborosan sebagaimana terkandung dalam surat Al-Israa' ayat 26-27 :

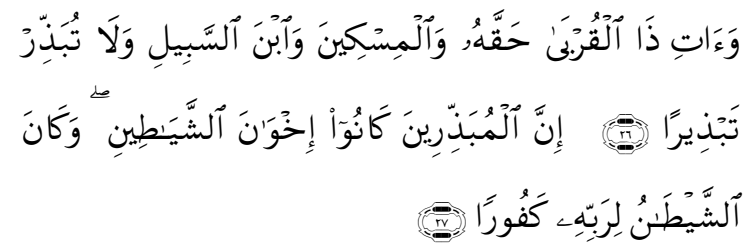

Wa ātiżalqurbā haqqahu walmiskiyna wa-ubnassabyili walā tubażżir tabżiyrā. Innalmubażżiriyna kā nuw ikhwānasy-syayā tiyni wakaānasysyayțānu lirabbihi kafuwrā

"Dan berikanlah kepada keluargakeluarga yang dekat akan haknya, kepada orang miskin dan orang yang dalam perjalanan dan janganlah kamu menghambur-hamburkan (hartamu) secara boros.[26] Sesungguhnya pemboros-pemboros itu adalah saudarasaudara syaitan dan syaitan itu adalah sangat ingkar kepada Tuhannya.[27]" (Departemen Agama Rl,2013: 284 )

Berdasarkan konsep tersebut diatas, maka konsep efisiensi operasional pembiayaan pada perbankan syariah merujuk pada keharusan manajemen bank untuk bisa mengelola pengeluaran untuk pos-pos penggerak biaya dengan cara yang tepat guna dan benar, hemat, layak, dan wajar.

Tujuan dari pembiayaan (Rivai, 2007:5) yaitu profitability atau tujuan untuk memperoleh hasil dari pembiayaan berupa keuntungan yang diraih dari bagi hasil yang diperoleh dari usaha yang dikelola bersama nasabah. Dengan melakukan fungsi pembiayaan, bank syariah akan memperoleh keuntungan baik berupa bagi hasil dan komisi.
Pendapatan bagi hasil dan komisi yang diperoleh bank syariah disisihkan sejumlah tertentu untuk administrasi, hasil bersih dari perhitungan ini merupakan laba bank syariah.

Jika pembiayaan mengalami peningkatan maka akan berpengaruh juga terhadap bagi hasil yang diterima oleh bank. Dengan demikian akan berpengaruh terhadap laba bank. Sehingga secara tidak langsung perubahan pada pembiayaan akan mempengaruhi laba bank. Keputusan pendanaan yang dilakukan secara tidak cermat akan menimbulkan biaya tetap dalam bentuk biaya modal yang tinggi, yang selanjutnya dapat berakibat pada redanya profitabilitas perusahaan (kartini dan Arianto, 2008). Dengan kata lain, keputusan pendanaan atau struktur modal sangat berpengaruh terhadap rendah atau tingginya profitabilitas suatu perusahaan.

Baik tingkat debt financing maupun tingkat equity financing memiliki pengaruh yang relative sama terhadap tingkat profitabilitas dan efisiensi biaya bank syariah karena pada debt financing tingkat keuntungan bank ditentukan di depan dan menjadi bagian dari harga atas barang atau jasa yang dijual. Pada equity financing tingkat keuntungan bank ditentukan dari besarnya keuntungan usaha sesuai dengan prinsip bagi hasil dimana keuntungan ditentukan oleh nisbah bagi hasil yang disepakati di muka, sedangkan baik debt financing maupun 
equity financing memiliki risiko kredit macet (Non Performing Finance) yang sama.

Jadi, pembiayaan Debt Financing akan memiliki pengaruh terhadap Profitabilitas bank khususnya pada tingkat profit yang dihasilkan dan efisiensi biaya. Begitupun dengan Equity financing akan memiliki pengaruh terhadap Profit Expense Ratio bank, karena baik debt financing maupun equity financing masing-masing memiliki prosedur yang berbeda dan menghasilkan bebanbeban yang akan ditanggung bank berbeda pula. Dan akan mengakibatkan tingkat Profit expense ratio yang berbeda pula

Berdasarkan pada rumusan masalah, tujuan dan landasan teori yang telah dijelaskan sebelumnya, maka hipotesis dari penelitian ini adalah sebagai berikut:

$\mathrm{H} 1$ : Terdapat pengaruh signifikan secara parsial pada debt financing terhadap profit expense ratio perbankan umum syariah

H2 : Terdapat pengaruh signifikan secara parsial pada equity financing terhadap profit expense ratio perbankan umum syariah

H3 : Terdapat pengaruh yang signifikan secara simultan pada debt financing dan equity financing terhadap profit expense ratio perbankan umum syariah
Model analisis pada penelitian ini dapat dilihat pada gambar 1 dimana penelitian menggunakan analisis regresi data panel.

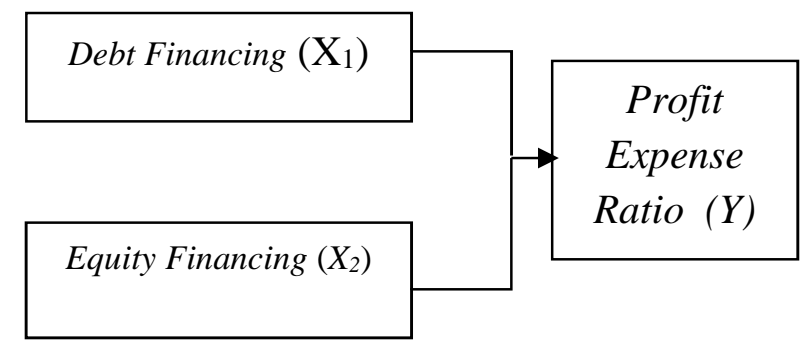

Gambar 1.

Model Analisis Pengaruh Debt Financing dan Equity Financing terhadap Profit

Expense Ratio

\section{METODE PENELITIAN}

\section{PENDEKATAN PENELITIAN}

Pada penelitian ini pendekatan yang digunakan adalah pendekatan kuantitatif. dengan metode regresi linear data panel yang diolah dengan menggunakan software Eviews 6

\section{Variabel independent :}

a. Variabel $X 1$ adalah debt financing

b. Variabel X2 adalah equity financing

\section{Variabel dependen:}

a. Variabel $Y$ adalah profit expense ratio (PER)

\section{Jenis dan Sumber Data:}

Jenis data dalam penelitian ini adalah data sekunder. Penelitian ini dilakukan dengan mendapatkan laporan keuangan publikasi yang dipublikasikan melalui media cetak dan elektronik dari laporan keuangan Bank Muamalat Indonesia, Bank Syariah Mandiri, dan BRI 
Firdaus, et al/Jurnal Ekonomi Syariah Teori dan Terapan Vol. 4 No. 6 Juni 2017: 505-514; PENGARUH DEBT FINANCING DAN EQUITY FINANCING TERHADAP PROFIT EXPENSE RATIO PERBANKAN UMUM SYARIAH PERIODE 2011-2015

Syariah. Penelitian berlangsung periode Januari-Desember 2016

\section{Populasi dan Sampel}

Populasi dalam penelitian ini adalah seluruh perbankan syariah yang resmi beroprasi di Indonesia dan terdaftar di Bank Indonesia sebagai regulator perbankan di Indonesia

Penelitian ini menggunakan teknik sampling yaitu Purposive sampling dengan kriteria

Kode A : Bank umum syariah di Indonesia yang beroperasi pada Januari 2011- Desember 2015

Kode B : mencakup sekurang-kurangnya telah beroperasi selama 5 tahun terhitung pada Januari 2016

Kode C:memiliki laporan keuangan triwulanan

\section{Teknik Analisis}

\section{Metode Regresi Data Panel}

Gujarati (2003:637) menjelaskan bahwa Data panel atau pooled data adalah kombinasi dari data time series dan cross section.

Menurut Widarjono (2007:251),
dalam data panel terdapat 3 pendekatan, yaitu Pool Least Square (PLS) atau disebut Common Effect, Fixed Effect (FE), dan Random Effect (RE). Pemilihan model estimasi data panel memiliki dua cara antara lain melalui uji F-statistik atau Chow Test dan Uji Hausman. Uji F-statistik digunakan untuk memilih pendekatan aman yang lebih baik antara PLS atau FEM. Sedangkan Uji Hausman digunakan untuk memilih pendekatan man ayang lebih baik antara FE atau RE. berikut adalah rumus untuk mencari F-statistik.

\section{Koefisien Determinasi (R2)}

Menurut Ghozali (2011:97), koefisien determinasi (R3) pada intinya mengukur seberapa jauh kemampuan model dalam menerangkan variasi variabel dependen.

\section{Uji Hipotesis}

\section{Uji Signifikansi Simultan (F Test)}

Uji statistik F pada dasarnya menunjukkan aapakah semua variabel independen atau bebas yang dimasukkan dalam model mempunyai pengaruh secara bersama-sama terhadap variabel dependen/tetikat (Ghozali, 2011:98). Dengan ketentuan tingkat signifikansi yang dipilih antara $5 \%$ atau $0,05(a=0,05)$, maka dasar pengambilan keputusannya adalah jika signifikansi $F$ hitung $<0,05$ maka $\mathrm{HO}$ ditolak, artinya terdapat hubungan antara variabel $X$ dan variabel $Y$ dan jika signifikansi $F$ hitung $>0,05$ maka $\mathrm{HO}$ diterima, artinya tidak terdapat hubungan antara variabel $X$ dan variabel $Y$.

\section{Uji statistik Parsial (t Test)}

uji statistik † pada dasarnya menunjukkan seberapa jauh pengaruh satu variabel penjelas atau independen secara individual dalam menerangkan variasi variabel dependen. Dengan ketentuan tingkat signifikansi yang dipilih adalah 5\% atau 0,05 (a=0,05), maka kriteria penerimaan atau penlakan $\mathrm{HO}$ yaitu $\mathrm{HO}$ ditolak : jika signifikansi t hutung < 0,05 artinya ada pengaruh antara variabel $X$ terhadap variabel $Y$ dan $\mathrm{HO}$ diterima : jika signifikansi t hitung $>0,05$ artinya tidak ada pengaruh 
antara variabel $X$ terhadap variabel $Y$.

\section{HASIL DAN PEMBAHASAN}

Tabel 1

\section{Hasil Pengujian Chow Test}

Redundant Fixed Effects Tests

Pool: POOL

Test cross-section fixed effects

\begin{tabular}{lrrr}
\hline \hline Effects Test & Statistic & d.f. & Prob. \\
\hline \hline $\begin{array}{l}\text { Cross-section F } \\
\begin{array}{l}\text { Cross-section Chi- } \\
\text { square }\end{array}\end{array}$ & 3.274108 & $(2,55)$ & 0.0453 \\
\hline \hline
\end{tabular}

Sumber: Eviews 6

Berdasarkan Tabel 1, diperoleh nilai probabilitas ( Cross-section F) sebesar 0,0453 lebih kecil dari a $(0,05)$ sehingga $\mathrm{HI}$ diterima, dan dapat disimpulkan bahwa Fixed Effect Model (FEM) lebih tepat dibandingan dengan Pooled Least Square/ Common Effect Model (CEM).

\section{Tabel 2}

\section{Hasil Pengujian Hausman test}

Correlated Random Effects - Hausman

Test

Pool: POOL

Test cross-section random effects

\begin{tabular}{lrrr}
\hline \hline Test Summary & $\begin{array}{r}\text { Chi-Sq. } \\
\text { Statistic }\end{array}$ & $\begin{array}{r}\text { Chi-Sq. } \\
\text { d.f. }\end{array}$ & Prob. \\
\hline \hline $\begin{array}{l}\text { Cross-section } \\
\text { random }\end{array}$ & 6.548216 & 2 & 0.0379 \\
\hline \hline
\end{tabular}

Sumber: Eviews 6

Berdasarkan Tabel 4.6, diperoleh nilai probabilitas (Cross-section random) sebesar 0,0379 lebih kecil dari a $(0,05)$ sehingga $\mathrm{Hl}$ diterima, dan dapat disimplkan bahwa Fixed Effect Model (FEM) lebih tepat dibandingkan dengan Random Effect Model (REM).

\section{Tabel 3}

Hasil Estimasi Fixed Effect Model (FEM)

Dependent Variable: PER?

Method: Pooled Least Squares

Date: 10/16/16 Time: 12:19

Sample: 2011Q1 2015Q4

Included observations: 20

Cross-sections included: 3

Total pool (balanced) observations: 60

\begin{tabular}{|c|c|c|}
\hline Variable & Coefficient Std. Error t-Statistic & Prob. \\
\hline C & $-0.8552430 .331361-2.581003$ & 0.0125 \\
\hline TDF? & 0.9418950 .3516282 .678665 & 0.0097 \\
\hline $\begin{array}{c}\text { TEF? } \\
\text { Fixed Effects } \\
\text { (Cross) }\end{array}$ & 1.1805640 .3557723 .318316 & 0.0016 \\
\hline \multirow[t]{2}{*}{ MUAMALAT--C } & 0.044412 & \\
\hline & -0.079394 & \\
\hline \multirow[t]{2}{*}{ BMS--C } & 0.034982 & \\
\hline & Effects Specification & \\
\hline \multicolumn{3}{|c|}{ Cross-section fixed (dummy variables) } \\
\hline \multirow{5}{*}{$\begin{array}{l}\text { R-squared } \\
\text { Adjusted R- } \\
\text { squared } \\
\text { S.E. of } \\
\text { regression } \\
\text { Sum squared } \\
\text { resid }\end{array}$} & Mean dependent & \\
\hline & $\begin{array}{l}\text { 0.399963var } \\
\text { S.D. dependent }\end{array}$ & 0.217087 \\
\hline & $\begin{array}{l}0.356324 \text { var } \\
\text { Akaike info }\end{array}$ & 0.144997 \\
\hline & 0.116330 criterion & -1.385112 \\
\hline & $\begin{array}{cl}0.744300 & \text { Schwarz criterion } \\
\text { Hannan-Quinn }\end{array}$ & -1.210583 \\
\hline Log likelihood & $\begin{array}{l}\text { 46.55336 criter. } \\
\text { Durbin-Watson }\end{array}$ & -1.316844 \\
\hline F-statistic & 9.165270 stat & 0.546160 \\
\hline Prob(F-statistic) & 0.000010 & \\
\hline
\end{tabular}

Sumber : Data diolah dengan Eviews 6

Berdasarkan hasil estimasi pada

Tabel 4.7 dapat ditulis bentuk persamaan

liniernya sebagai berikut:

PER $=-0.855243+0.941895 \mathrm{TDF}+1.180564 \mathrm{TEF}$

Berikut ini adalah interpretasi dari nilai koefisien regresi:

1. Apabila seluruh variabel independen tidak mengalami perubahan atau konstan, maka PER sebesar -0.855243

2. Apabila variabel TDF mengalami peningkatan sebesar satu satuan 
Firdaus, et al/Jurnal Ekonomi Syariah Teori dan Terapan Vol. 4 No. 6 Juni 2017: 505-514; PENGARUH DEBT FINANCING DAN EQUITY FINANCING TERHADAP PROFIT EXPENSE RATIO PERBANKAN UMUM SYARIAH PERIODE 2011-2015

sedangkan variabel independen lainnya dianggap konstan, maka PER akan mengalami peningkatan sebesar 0.941895 satuan, begitupun sebaliknya

3. Apabila Variabel TEF mengalami peningkatan sebesar satu satuan sedangkan variabel independen lainnya dianggap konstan, maka PER akan mengalami peningkatan sebesar 1.180564 satuan, begitupun sebaliknya.

\section{Koefisien Determinasi $\left(\mathbf{R}^{2}\right)$}

Berdasarkan Tabel 3, dapat diketahui bahwa nilai $\mathrm{R}^{2}$ sebesar 0.346202 . Hal ini menunjukkan bahwa variabel TDF dan TEF dapat menjelaskan PER sebesar $39,99 \%$ sedangkan sisanya sebesar $60,01 \%$ dijelaskan oleh variabel-variabel lain diluar model atau diluar variabel-variabel yang diteliti.

\section{Signifikansi Simultan (FTest)}

Berdasarkan Tabel 3, diketahui tingkat probabilitas (F-Statistic) sebesar 0.000010 yang lebih kecil dari a $(0,05)$, sehingga $\mathrm{HO}$ ditolak dan dapat disimpulkan bahwa Debt financing dan Equity Financing secara simultan berpengaruh signifikan terhadap Profit Expense Ratio

\section{Uji Statistik Parsial ( $\uparrow$ Test)}

Berdasarkan Tabel 4.7, maka pengujian terhadap hipotesis pengaruh masing-masing variabel independen terhadap variabel dependen dapat dijelaskan sebagai berikut:

1. Variabel TDF memiliki tingkat probabilitas (t-statistic) sebesar 0.0097 yang lebih kecil dari a $(0,05)$, sehingga H02 diolak. Kesimpulan yang dapat diperoleh adalah TDF berpengaruh signifikan terhadap PER.

2. Variabel TEF memiliki tingkat probabilitas (t-statistic) sebesar 0.0016 yang lebih kecil dari a $(0,05)$, sehingga H03 diolak. Kesimpulan yang dapat diperoleh adalah TEF berpengaruh signifikan terhadap PER

\section{Pembahasan}

Pengaruh Debt Financing dan Equity Financing Secara Simultan terhadap Profit Expense Ratio

Hasil penelitian ini menunjukkan bahwa TDF dan TEF secara simultan berpengaruh signifikan terhadap PER. Hal in iterlihat dari tingkat probabilitas (Fstatistic) lebih kecil dari a $(0.000010<$ 0,05), sehingga $\mathrm{H}_{01}$ ditolak dan dapat disimpulkan bahwa variabel TDF dan TEF secara simultan berpengaruh signifikan terhadap PER.

Hasil penelitian ini menunjukkan bahwa pertimbangan pemberian pembiayaan mempunyai peran penting dalam efisiensi perbankan syariah

\section{Pengaruh Debt financing (TDF) terhadap Profit Expense Ratio (PER)}

Pengaruh TDF terhadap PER secara parsial dapat dilihat dari hasil tingkat probabilitas (t-statistic). Berdasarkan hasil pengelolahan data diketahui bahwa tingkat probabilitas (t-statistic) lebih kecil 
dari a $(0.0097>0,05)$, sehingga $\mathrm{H}_{02}$ ditolak dan dapat disimpulkan bahwa TDF berpengaruh signifikan terhadap PER. Hal ini dapat menggambarkan beberapa hal yang berhubungan dengan transaksitransaksi yang ada.

Dengan besarnya pembiayaan ini beban operasional maupun non operasional yang dihasilkan akan memengaruhi Profit Expense Ratio Bank Syariah yang bersangkutan. Dapat diartikan semakin besar Debt Financing semakin tinggi pula Profit Expense ratio.

\section{Pengaruh Equity Financing (TEF) terhadap Profit Expense Ratio (PER)}

Pengaruh TEF terhadap PER secara parsial dapat dilihat dari hasil tingkat probabilitas (t-statistic). Berdasarkan hasil pengelolahan data diketahui bahwa tingkat probabilitas ( $\mathrm{t}$ statistic) lebih kecil dari a $(0.0016<0,05)$, sehingga $\mathrm{H}_{03}$ ditolak. Kesimpulan yang dapat diambil adalah TEF berpengaruh signifikan terhadap PER.

Nasabah yang menggunakan sistem pembiayaan equity financing lebih berorientasi pada modal kerja. Mereka memanfaatkan untuk membiayai usaha usaha mereka dengan maksud untuk saling menanggung laba dan rugi bersama-sama, sehingga resiko kebangkrutan dapan diminimalkan dengan syarat kedua belah pihak dapat menerapkan kejujuran dalam pelaksanaannya.

Hal ini menunjukkan semakin baiknya perkembangan equiy financing dari segi total pembiayaan maupun jumlah nasabah baru dari tahun ke tahun. Besar kemungkinan terjadi perubahan pola pikir masyarakat luas yang beralih dari Bank Konvesional ke Bank Syariah.

Equity Financing juga menjadi variabel yang dominan dalam mempengaruhi Profit Expense Ratio dilihat dari nilai Coefficient yang lebih besar dibanding dengan nilai Coefficient debt financing yaitu sebesar 1.180564.

\section{SIMPULAN}

Berdasarkan hasil dan pembahasan pada bab empat, maka kesimpulan yang dapat diambil dari penelitian ini adalah sebagai berikut:

1. Debt financing dan Equity Financing secara simultan berpengaruh signifikan terhadap Profit Expense Ratio

2. Debt financing berpengaruh signifikan terhadap Profit Expense Ratio

3. Equity Financing berpengaruh signifikan terhadap Profit Expense Ratio dan menjadi variabel yang dominan.

\section{DAFTAR PUSTAKA}

Antonio, M.Syafi'l Dkk. 2006. Bank Syariah, Yogyakarta: Ekonesia

Departemen Agama RI Proyek Pengadaan kitab Suci Al-Qur'an, AlQur'an dan terjemahnya, Jakarta: CV Indah Press, 2013.

Gujarati, Demodar N dan Dwan C. Porter. 2013. Dasar-Dasar Ekonometrika. Edisi 5 Buku 2. Jakarta: Salemba Empat. 
Ghozali, Imam. 2011. Aplikasi Analisis Multivariate dengan Program IBM SPSS 19. Semarang: Universitas Diponegoro Ismail, 2011, Perbankan Syariah. Jakarta: Kencana Prenada Media Group

Kartini, dan Tulus Arianto, 2008, Struktur Kepemilikan, Profitabiltas,

Pertumbuhan Aktiva dan Ukuran Perusahaan Terhadap Struktur Modal pada Perusahaan Manufaktur. Jurnal Kevangan dan Perbankan. Vol 12. No 1. Hal 11-21

Kamaruddin, Badrul Hisham,et.al. 2008. Assesing Production Efficiency of Islamic Banks and Conventional Bank Islamic Window in Malaysia. International Journal of Business and Management Science, Vol 1(2),pp.3148Ismail, 2011, Perbankan Syariah, Jakarta: Kencana Prenada Media Group

Machmud, Amir, Rukmana. 2010. Bank Syariah : Teori, Kebijakan dan Studi Empiris di Indonesia. Jakarta: Erlangga.

Muhammad. 2002. Kebijakan Fiskal dan Moneter dalam Ekonomi Islam. Yogyakarta: BPFE-UGM

Pudjo, Mulyono.1995. Analisis Laporan Keuangan untuk Perbankan. Jakarta: Djambatan.

Rivai, Veithzal dan Andria Permata Veithzal, 2008, Islamic Financial

Sadique, Muhammad Abdurrahman, 2010, Islamic Banks Dilemma Between
Ideals and Practice: Debt or Equity. Global Journal of Management and Business Research. Vol 10.

Samad, Abdus dan Hassan, M, Khabir, 1999. "The Performance of Malaysian Islamic Bank during 1984-1997. Islamic International Journal of Financial Services 1999: An Exploratory Study", (online),

(http://www.iiibf.org/journal.html diakses 20 November 2015)

Wirdyaningsih. 2005. Bank dan Asuransi Islam di Indonesia. Jakarta: Prenada Media.Management. Jakarta: Raja Grafindo Persada

Widarjono, Agus. 2007. Ekonometrika Teori dan Aplikasi. Yogyakarta: Ekonisia. 